\title{
Legal and Sociological Analyses on Telework at Home in Brazil
}

\author{
Márcia Regina Castro Barroso \\ Doctoral Student in Sociology from Universidade Federal do Rio de Janeiro, UFRJ, Rio de Janeiro, Brasil \\ Email: marciajose@ig.com.br
}

Received 16 April 2014; revised 30 May 2014; accepted 15 June 2014

Copyright (C) 2014 by author and Scientific Research Publishing Inc. This work is licensed under the Creative Commons Attribution International License (CC BY). http://creativecommons.org/licenses/by/4.0/

c) (i) Open Access

\begin{abstract}
This text is a small adaptation of our Master-degree's dissertation, which had telework performed in Brazilian homes as its main goal. The research as a whole focused on both sociological and legal analyses of the aspects of telework, regarding flexible work schedules, legislation on distance work, hierarchical relationships, space and time organization of work utilizing telematic means, as well as perceptions of the actors involved with this activity. In this paper, the legal aspects of telework in Brazil will be emphasized.
\end{abstract}

\section{Keywords}

\section{Telework, Distance Work, Work Relationships}

\section{Introduction}

This study focuses on the so known telework, with special attention to the one performed at home. This sort of work has been increasing in Brazil, just as in the entire world, mostly after the 1990's, moved by the wider process of transformations in the world of labor.

Telework has main characteristics of the utilization of new information and communication technologies, and the performance of labor activities out of the enterprise. Telework is not restricted to the work performed at home. Its possibilities are diversified and embrace a wide heterogeneity of tasks and functions. In the case of the present research, to delimitate its object, the focus was placed on work performed at home, due to its particular interest for the study of new tendencies in the labor world.

But what is telework all about? How can it be defined? Labor legislation in Portugal—a country which has specific legislation on telework - telework is considered to be the one regularly performed, under legal subordination, out of the enterprise through use of information and communication technologies ${ }^{1}$.

${ }^{1}$ Código do Trabalho Português, 2009. Available in: http://www.legix.pt/docs/CT0915_Set_2009.pdf, p. 76. 
From a symbolic standpoint, telework at home involves important matters to consider, as it concerns hierarchy, as well as time and space experiences. In the case of home telework, the worker himself provides the space for the performance of tasks, thus the enterprise becomes free from that responsibility.

However, it is difficult to find reliable data on this labor activity. Very often it is difficult to distinguish between "exaggeration" and reality in the information of those who have the objective of disseminating this work modality (enterprises, associations, reviews specialized in administration and finance). The access to the workers is also difficult, due to the "displacement" of their activities, even greater in the case of those who work at home. Anyway, some quantitative data on these workers are provided here.

In Brazil, several enterprises already utilize this modality of work, such as Dell, Gol, Xerox and Shell ${ }^{2}$. According to Sociedade Brasileira de Teletrabalho e Teleatividades (SOBRATT), the number of teleworkers in the country has been estimated to be around 10.6 millions of individuals, considering the different modalities ${ }^{3}$. O Annuaire des télétravailleursindépendants, an association for advisory and assistance services to telework in France, estimates that $18 \%$ of the workers in Europe may be considered teleworkers, $8 \%$ of them in France. The same association comments that in the United States (in 2005) around 135 million workers were considered teleworkers ${ }^{4}$.

We should emphasize that not all professional activities can choose this decentralized work system. Among the professional categories that perform these activities, we can find computing professionals, journalists, translators and other service providers.

Our main hypothesis, which has been a guiding line for this work, refers to the impossibility of decoupling private life and labor life, in the case of telework at home. What could this impossibility imply, in terms of losses in the living standards of teleworkers? Therefore, we tried to understand the rise of new social dynamics in the execution of this kind of work, most of which related to new perceptions of time and space. In this sense, particular attention was given to the aspect of home space as a work space and the issue of the practical possibility of a "flexible work journey". Our reflection also dealt with the issue of subordination in distance work: the issue of regulation of this kind of work and control of work relationships, as well as the issue of professional identification by these workers and how this aspect reflects on a possible (or "difficult") collective organization.

The fact that work may be done at home (or at least part of it) can lead to no differentiation between working time and rest time, leisure time. This kind of activity requires a strong self-control from the workers, in relation to the organization of their time-schedule. Otherwise, the limits between the periods of work and leisure may become fragile and mixed up. It is also our opinion that the fact that wage earners perform their tasks at distance does not eliminate the employment relationship, since the subordination through symbolic mechanisms of power still remains.

\section{Legal Aspects of Telework}

Since we have already done the considerations about the definition of telework and its developments, this section of the article will deal with issues within the legal sphere. First of all, we will analyze the historical and social context in which telework is inserted, due to a new social organization of work. Consequently, the new challenges for the legislation on labor will also be approached. Concepts such as flexibility, autonomy, and others have received special attention in the conceptions related to ways of organizing companies. Regarding these matters, jurists and researchers of labor rights have deeply studied how to face the new challenges.

Here we will deal directly with the salary earner teleworkers and the protection systems granted to them by the labor relations already established. Therefore, the characterization of the subordination to an employment relationship is an issue of great importance for the distance work. In attention to our study's object, a new concept was used, that of symbolic subordination, through which we attempt to identify the subjective elements beyond those formally established in a contractual relationship.

And finally, we will analyze a legislation that copes with telework performed at home as a form of distance labor activity.

\subsection{Present Challenges for Labor Laws}

Just as we can say that the world of labor is no longer the same it was in the $20^{\text {th }}$ century, labor rights, through

${ }^{2}$ Internet \& Cia. See: http://www.fenacon.org.br/fenacon informativos/jornalcom/jornalcomercio07082002a.htm access: Oct/20/2011.

${ }^{3}$ See: http://www.sobratt.org.br. Access on Oct/18/2011.

${ }^{4}$ See: http://www.teletravail.fr. Access on Oct/18/2011. 
their theoreticians and jurists, have also followed the changes that occurred, trying to redefine their role in society. The relations between State, companies, workers and labor unions have had important changes, just as their role. In the attempt to provide a general panorama of these transformations, we took into special consideration the thoughts of an important and influential French intellectual, Alain Supiot, who dedicated himself to the study of labor rights, within the context of permanence and widening of social rights. According to him, social rights have consolidated mainly from the conformation of labor rights. We will use his works Au-Delà de L'employ (1999) and Homo Juridicus (2007) for this role-based context definition.

For Alain Supiot, the socioeconomic model of regulation, adopted by Labor Law during the $20^{\text {th }}$ century, is now in crisis. This may be verified from an institutional perspective and in the internal organization of companies as well. He makes a distinction between Labor Law conceived according to a For dist type of organization of companies, and the emergence of reorganization of labor, and the crisis of these rights, because they do not fulfill those areas still considered "nebulous" or undefined, as we will see ahead.

The For dist enterprise, where the conception and the labor execution are separated, has wage practices associated to a fixed work journey and to a determined work position. The union in the For dist type is active, with focus on the activities sector. The State is Keynesian, protectionist, conciliator, the instance for institution of mechanisms of social negotiation. Labor Law is standardized, based in the dual relation of subordinate work/ independent work, granting a passive individual worker security, a homogeneous working schedule and relatively autonomous collective negotiations. We can see clearly that Supiot's work emphasizes the analysis of the European model.

The reorganization of work within the companies changed the distinction between conception and execution, especially due to the appearance of products that are out of pattern and, as a consequence, the labor activity itself becomes more flexible. Another factor Supiot deals with is the massive insertion of women in the work market, which, according to him, undermines the patriarchal For dist model. Work stability gave way to sporadic contracts, no longer defined exclusively for one specific work position [1].

Taking into consideration these transformations, Supiot points out two tendencies: the increase of contractual relations, based on the work contract, and the protection against risk, or else the choice for flexible relations, either through non submission of the collective actor to the State framework, or the proclamation of social rights disconnected from the individuals' insertion to the economic sphere [1].

The contractual formats also change, while new ways for workers' operational autonomy are created. As it concerns to Law, at least in the European countries, there is a tendency for the legislation to widen the field of its authority, embracing, for instance, forms of independent work.

As regards the matter of Social Law, we can notice some effects of this process. First, the issue of people's insecurity. Lately, the idea that workers have to be independent and do not need to join unions has been propagated. This undermines the strength of professional categories as collective actors. Besides this issue of the organization and workers' mobilization, we must consider the formation of a "grey zone", to use Supiot's expression, which is placed between the independent and the dependent work. Some people are legally treated as independent, but are dependent on economic terms, just as, possibly, of some type of command (for instance, the demands of a client). While on the other hand, some workers might be legally dependent, but actually, in their routine activities, they are autonomous workers.

Considering the aspects that have been presented, Supiot calls attention to the need to reaffirm the fundamental principle that work relations are not based exclusively on their legal qualifications. The author emphasizes the need to widen the field of application of Social Rights, in order to include more than just subordinated workers. Therefore, he proposes that work rights should include workers that cannot be considered as wage earners, but who are living in a situation of economic dependency. We must also mention that Supiot's greatest concern is the issue of regulation work with respect to the consolidation of the European Union [1].

In another work, in Homo Juridicus (2007), where he makes an essay on the anthropological function of Law, Supiot also comments the new context in which Labor Law is integrated. In the following extract we can observe, concisely, his perception about the present transformations:

"Since the mid-1970s, the Labor Law is involved with the individualization of the statutes. The salary earner employment has diversified with the erosion of typical employment, which associated dependency and security; the individual contract gained a new importance; the frontiers between salary earners and independence, private life and professional life, were shuffled. Subordination acquires new faces, while the economic power 
emerges in the intertwining of nets of companies. The reduction of duration of work goes along with the increase of its intensity. Here also Law and technique go in the same pace; the autonomy in the subordination could not progress in the salary world without the help of the microcomputers and the cellular telephones, which allow for work and control at any place and any time." [2].

As this panorama was portrayed, upon the thoughts of Supiot, we can notice that the central point of his analysis is the question of how Labor Law will be configured after the transformations that occurred in the arena of work. Supiot's position is clear: Labor Law needs to adapt itself within the new reality, without losing sight of its protective aspect, where social rights are intimately linked to labor rights. From this premise, we highlight the matter of the characterization of subordination in a labor situation. Social rights have to overcome the classical characterizations of subordinated work. However, inserting these new forms of subordinated work into the labor legislation is yet a great challenge for the jurisdiction of the so called labor world.

\subsection{The Subordination in the Work Relationships: Its Symbolic Aspects}

The term "subordination", from an etymological line of interpretation, may be understood through the notions of dependence or obedience in relation to a hierarchy of positions or values (Delgado, 2008: 302) [3].

In free and salary earning work, there is consensus among researchers on Labor Law that a juridical subordination must be considered as one of the most important characteristics of a work relationship. However, we call attention to the difference between the concepts of exploitation and subordination. Subordination in itself does not imply exploitation of a man by another man (Alemão: 2004) [4]. But, once employers benefit from the profits obtained by the appropriation of the work surplus, there will be an effective economic exploitation, often made possible by the subordinated situation to which the worker is submitted.

For Otávio Pinto e Silva, who studied the matter in-depth, the criteria of juridical subordination involves command and direction from the employer, while subordination is the passive aspect of power. As a result of this relationship, the employer would have the power to control and monitor the worker's activity.

Evaristo de Moraes Filho adds that in juridical subordination the employer's right to give orders, to interfere in someone's activity and set limits, prevails. This is different from a specifically economic subordination (Morais Filho, 1994: 105) [5]. He also says that some authors consider direction and constant surveillance as one of the elements of subordination. However, Morais Filho comments that it is necessary to widen such concept, since distance work does not imply the end of subordination. Monitoring and controlling do not need to be constant and permanent in order to characterize subordination. But it also consists on the right the employer acquires to interfere in work performance and, therefore, to establish a power relationship. A right which perhaps is not exercised in an explicit way, but is present in a subliminal way in the relationship of employment.

Given the complexity in which companies organize their production, utilizing infinite decentralized branches of production; their agents become almost anonymous, "lost" in a multitude of intermediaries (Morais Filho, 1994: 107) [5]. Hence, the criteria of identification of a relationship of subordination are more psychological and subjective, therefore decreasing the material criteria with physical visibility. In this way, the elements of personal nature are not to be forgotten in a relationship of employment. Thus, the establishment of a relationship based on trust and fidelity criteria occurs.

Arion Sayão Romita [6], in his book A subordinação no contrato de trabalho (1979: 79-81), is critical of the vision of subordination which only takes into account direction and supervision, command power and obedience. For this author, the link that effectively links the worker to his employer is the activity exteriorized in the work relation. The author emphasizes the issue of worker activity, as it would really be present in the company's organization.

For Otávio Pinto e Silva (2004: 17) [7], if the aspect of subordination were considered by taking into account the worker activity, some consequences could be foreseen from this thought. The first aspect refers to subordination, not as a worker status, since he is not the object of the work contract, but rather his activity. Therefore, what is submitted to the power of the employer is the activity. Another aspect would be interpreting the subordination not as a hierarchical link, as the worker has the guarantee of breaking the contract whenever he wishes. Furthermore, "the subordination does not require the effective and constant action of the employer in the legal sphere of the worker, but rather the mere legal possibility of this intervention” (Silva, 2004: 18) [7].

In order to introduce the subordination aspect into telework, we defined the expression symbolic subordina- 
$t^{5}{ }^{5}$, as a sociological situation that goes beyond the legal subordination analyzed by the doctrine of the Work Law. It is a manifestation which transcends the legal and contractual rules, creating an affectionate relationship between the parts. This situation could make the worker more vulnerable, when it strengthens the ties of domination. Such affectivity may occur directly with the employer, in a small business, but it also happens in the large businesses, through the superiors in the hierarchy, who loyally reproduce the will of the employer. In some cases the symbolic subordination may reach the production line of the company, although this will never be expressed formally, since it is not a discipline rule, but an affectionate relationship within a type of social domination.

The symbolic subordination transcends the context of juridical and economic subordination. While the juridical subordination refers to the obligations that are established based on the work contract and law, the symbolic subordination implies the formation of a personal relationship of cooperation and even gratitude. The employee may feel in debt towards his employer, and the employer may be seen as a benefactor, as a person that granted some type of benefit. Furthermore, the employer may also feel he has the right of demand on the employee beyond what has been established in the contract, or in the law. Here we can notice the existence of a tenuous limit between the symbolic subordination and what is known as "moral harassment". In our case study, we analyze the ways of elaboration of powers in the limits of the established legal order. In this sense, the great difference consists in the existence of consent that permeates the actions of the involved subjects.

Symbolic subordination is thus understood as a concept, or a cultural value, which may influence people's behavior and, as a consequence, decision making. Such notion is associated to a dependent condition, based on personal criteria, which implies the valorization of elements such as loyalty and trust.

An author who helps in the reflection about symbolic subordination is Bourdieu, when commenting on the differentiation of powers and circuits of domination, in his book Meditações Pascalianas (2001: 125) [8]. Bourdieu indicates the existence of a complexity of power actions in the established social relationships, often invisible or anonymous, which, even if they seem anarchical, are indeed establishing a structure where constraint is present. The agents and institutions are inserted into fields that are involved in legitimating exchange circuits with increasing complexity, and therefore even more effective in symbolic terms.

Still in O podersimbólico (Portuguese edition of Symbolic power, 2009), Bourdieu analyses some issues regarding symbology. The symbolic systems, seen from the perspective of the constitution of powers, have the capacity of creating conditions for domination actions, without necessarily explicit relationships, requiring too much expenditure of energy. These symbolic systems obtain consent through the elaboration of certain legitimating images. By the use of language, images, speeches, the symbolic systems favor the organization of some social relationships (Bourdieu, 2009: 14) [9].

This way, the symbolic systems can be understood as fundamental elements in the elaboration of domination powers, which, although invisible, have the complicity and consent of all those involved in a social relationship. Thinkers of Kantian trend also see the active aspect of all symbolic production. The symbolic universes such as myths, language, art and sciences are understood as instruments of knowledge and construction of the world of objects, through the "symbolic forms" (Bourdieu, 2009: 8) [9]. At this point, we can recall the work of Durkheim and Mauss (1981) [10] who, in their book Algumasformasprimitivas de classificação, understand that even the classificatory systems are forms of symbolic ordination of social activities.

In telework, in particular the one done at home, issues related to symbolic subordination are very important. The physical distance is far from meaning a removal from symbolic subordination. But the matters that we want to clarify here are the following: how can we understand the notions of "commitment" and "control", regarding distance work, which it is to say, without direct control by the employer in this relationship of employment? How does subordination take place in this type of work and how can we understand its mechanisms of realization.

As the productive activity is reorganized, mainly from the years 1970 onwards, new organizational forms appear, mostly those which privilege notions of flexibility ${ }^{6}$. The concepts of adaptation, change and flexibility

\footnotetext{
${ }^{5}$ The expression symbolic subordination was defined from a joint reflexion with Ivan Alemão, in a study in which we joined two researches, one about self-administration in the relationship of employment and the one about telework. From these two study cases, we developed the idea about a subordination that goes beyond the contractual relationship of work. Here, we are going to consider only a few aspects of this study. We add much more information, deepening the concept in the reflexion about telework done at home. For further information see: ALEMÃO, Ivan, BARROSO, Márcia R.C. (2011) “A Subordinação simbólica: Mecanismos de dominação no mundo do trabalho”. Trabalhoem Revista (Impresso), v. 172, pp. 6179-6190.

${ }^{6}$ About entrepreneurial reorganization in specific, major attention will be given to the chapter in which we talk about new formats of company management.
} 
gained amplitude and were intensified, especially through the diffusion of new technologies. Within this context, workers were "called" to become more creative and autonomous (in the sociological sense of the term), while they became directly responsible for their own professional qualification and their capacity to adapt to new jobs and functions.

As for telework done at home, we could observe in interviews both with entrepreneurs and teleworkers, that the issue of control was not emphatically mentioned, nor was it mentioned as being important to the employment relationship. However, what we want to demonstrate, through the expression symbolic subordination, is that, although this labor control was not too explicit in the distance work, it is present through the symbolic systems of power. A superficial analysis would show that the teleworker is under a weaker bond of subordination, since there is not a rigid control by the enterprises, letting the worker organize his time-schedule and so on. However, we call attention to the substitution of a system of external control by a system of internal control in the home telework, where the worker himself adheres to notions of self-control, taking on total responsibility for his activities. He does not need a person to tell him all the time what he has to do, nor what time he goes out for lunch. The very notion of work journey is dispersed in the notion of valorization of the compliance to tasks ${ }^{7}$. In this sense, the business institutions are present in the lives of their employees, through a symbolic relationship of power, based on criteria of loyalty and trust.

However, when we mention the existence of these symbolic mechanisms of power, we also have to comment the existence of other forms of control, such as, for instance, the constant phone calls made during the day, the exchange of emails that are constantly answered, the reports, and so on. About this matter of exchange of emails, the limits of the working journey are often disregarded, either in relation to the rest of week-ends or in relation to evening schedules as well.

Richard Sennet [11], in his book, A corrosão do caráter (2007), makes an interesting reflection about this substitution in the ways of workers control. It is useful to reproduce some of his thought at this point:

"Workers, therefore, change a form of submission to power, face to face, for another, which is electronic. It was what Jeannette found out, for instance, when she moved to a more flexible job, in the East. The micro-administration of time advances rapidly, even when time seems deregulated, in comparison with the problems of Smith's pin factory or Fordism. The metrical logic of Daniel Bell's time moved from staff clock in to the computer screen. Work is physically decentralized, power over the worker is more direct. Working at home is the last island of the new regime.

"These are, therefore, the forces that submit people to change: reinvention of bureaucracy, flexible specialization of production, concentration without centralization. In the rebellion against routine, the appearance of new liberty is misleading. The time in institutions and for individuals was not liberated from the iron cage of the past, but subjected to new controls from above. The time of flexibility is the time of a new power" (Sennett, 2007: 6869) [11].

Regarding the issue on the working journey's limits in telework, in practice it is unfeasible to define frontiers among the moments for rest and the moments for work. Rest, formerly a well-defined right in a contract, became a hypothesis which is not always feasible. In telework, the employee's privacy can be more deeply exposed. If, in an enterprise, the privacy of the employee can be affected, for instance when he is searched, in telework system the employer, in a way, ends up penetrating the personal life of the employee in his own house. The employee may have, in his private environment, the invasion and control of his behavior by the company's organizations.

The employee who is subordinated by means of telework lives, therefore, with his mind constantly turned towards his work. His adherence to the proposals of work is such that it may imply in the intensification of his rhythms of work, as well as decrease in his pauses during the performance of the tasks.

The teleworker is attracted by the possibility of flex time, which would therefore allow him to combine home tasks to the professional ones. The worker becomes fascinated with the possibility of "freedom from routines", but at the same time, he may be submitted to a much more intense rhythm of work.

In the interviews, this aspect was pointed out several times. In fact, the topic of the possibility of flexibility practices in work schedules was often mentioned and presented as a stimulus for this type of worker. However, the topic of isolation and difficulty to solve basic administrative matters was also indicated. This, if the worker were in the same work space, would be more easily solved, according to them. Not to mention the difficulty in obtaining the recognition for the performance of a task. The delivery of the results, the accomplishment of the

\footnotetext{
${ }^{7}$ The matter of work journey will also be seen ahead, when we analyze the thought of theoretitians about telework.
} 
tasks from the distance, allows for the absence of personal contact, establishing new sociabilities, which implies isolation of these teleworkers. Even about this recognition, one of them called our attention: “(...) we work, work, work, but it seems as if we always owed something." ${ }^{8}$ This same person still mentioned that in the beginning, when she started working at home with sales, she woke up at $06 \mathrm{~h} 30 \mathrm{AM}$ to start her activities, but when she realized it, she had gone over lunch time ${ }^{9}$.

Work, therefore, in this type of activity, reaches unexpected proportions until then, installing a new central sphere, while the body, affectionate and family dimensions are mixed.

\subsection{Telework and Labor Legislation in Brazil}

Work performed at home, with handcraft, is not a novelty and has been done for a long time. Regarding the work legislation protection, both for handcraft and for home telework, the greatest difficulty relies on the recognition of the characteristics of subordination of an employment relationship. The corpus of labor legislation in Brazil called "Consolidação das Leis Trabalhistas" (CLT), in their initial conception, with respect to work paid in wages, presents the issue of subordination as fundamental for the characterization of the existence of an employment relationship. We saw previously that the subordination may be seen from different views, but the interpretation that interests us relies on the bond that links the worker to his employer, through the activity that is exteriorized in the work relationship. Therefore, the fact that the activity can be performed in an environment which is distant from the employer's head office does not make it unfeasible to prove the existence of legal subordination. To a certain extent, CLT itself, in its sixth article, already predicted this non-differentiation. As we can see, it suggested the same legal treatment to those who perform their activities from the distance: "Work performed at the employers facilities cannot be distinguished from worker performed at the worker's home, as long as the employment relationship is characterized."

We still find another reference in CLT regarding work done at home in article $83^{\text {rd }}$, which, when making comments on the issue of minimum remuneration, ends up raising a definition for work performed at home, as such: "It is due to the minimum wage paid to the worker at home, this being considered as the one which is performed in the home of the employee or his family's office, on behalf of the employer who pays him."

In this sense, when you have a labor complaint, regarding the work performed at home, usually legal practitioners refer to these articles in order to base their decisions, dedicating themselves to verifying, in each case, whether an employment relationship exists or does not exist.

However, this legislation does not cover the cases in which work is performed from a distance, which is not done at the employee's home, as in the example, but rather in the "satellite offices" or travelling work. Regarding this matter, we will not deepen the discussion, as this is not the topic of our research. However, we could not avoid mentioning the existence of these workers who can perform their activities in a decentralized way.

In the case of telework, which could be analyzed taking as a reference the $6^{\text {th }}$ article of Brazilian CLT (Consolidação das Leis Trabalhistas), it recently received a great legal incentive for its possible and probable expansion. On December $15^{\text {th }}$, 2011 a new law was passed, number 12.551, including a paragraph in the $6^{\text {th }}$ article, which has already been mentioned. Just one line was added, but it has caused much controversy, mainly in the legal and entrepreneurial environments. The paragraph that was added says the following:

"Single paragraph. The telematic and computerized means of command, control and supervision have been equaled, regarding legal subordination, to the personal and direct means of command, control and supervision of someone else's work".

For many people, this law did not bring significant changes to the terms presented in the $6^{\text {th }}$ article. However, the main discussion that has been intensified since the promulgation of law 12.551, refers to the payment or not of extra hours resulting from the use of cellular phones, pagers, e-mails, etc.

It is true that this approach already existed to some extent in the discussions about the disputes over CLT's $62^{\text {th }}$ article and the alert. However, beyond the discussion of the control of the work journey, we can also observe the presence of a great problem regarding the inspection of this worker's environment and conditions of work. The new law only treats the issue of subordination and the instruments for control of this work relationship. However, about the details, the contractual obligations, such as, for example, who will be in charge of costs (energy, furniture etc.) these aspects have not been regulated.

\footnotetext{
${ }^{8}$ Interview held in April, 2010, with a teleworker of a large sales company.

${ }^{9}$ At another moment in this work, we will give special attention to the talk of teleworkers as well as other actors involved in this productive activity. But we think it is better to highlight the aspects that are most relevant to this topic.
} 
In the Brazilian case, since 2008, a law Project, number 4505, has been presented, trying to regulate distance work, conceptualize and discipline the work relationships in telework. The author is Congressman Luiz Paulo Vellozo (PSDB-ES). In this project of law, the most controversial topic refers to the concept of "open journey" that was used which, due to the characteristics of control, generally done in a virtual way, favors the argument that the telework employees should not be granted the right to overtime, therefore the payment should be adjusted to the regular hours of work ${ }^{10}$. This project of law has ten articles and predicts a series of details in the contractual relationship of telework, which go from a definition of what is telework, to the employer's obligations towards the teleworker. It is interesting to observe that the concept of telework which was developed in this project of law is not restricted to the worker who earns a wage. The definition is widened, to also include the autonomous workers, as we could observe:

"First Article. For the purposes of this law, telework is understood as all types of work developed under the control of the employer or for a client, by an employee or autonomous worker in a regular way and for any amount of time which is superior to forty percent of the time work in one or more diverse places of work, for which computing and telecommunication technologies are used.” (Sixth Article of law project 4.505).

This project has already been approved in several instances, including its constitutional nature, by the Comissão de Constituição, Justiça e Cidadania (CCJC) (Committee on Constitution, Justice and Citizenship) and it is presently waiting for approval at the House of Representatives and at Senate ${ }^{11}$.

Some companies, in order to avoid possible labor demands, are consulting professional unions involved, before signing collective agreements on the system of telework.

One of the companies that was researched, the company that provides services in the area of computing (technical assistance, software sales and others), from Rio de Janeiro, established two documents aiming at the obtention of legal support for the adoption of telework system. One of them: a Commitment, signed by the employer and the teleworker; and a collective agreement, signed by the company and the institutions of union representation, which, in this case, were the Union of Computing and similar services workers of Rio de Janeiro (SINDPD$\mathrm{RJ}$ ) and the Union of the computing companies of the State of Rio de Janeiro (SEPRORJ).

As we could see in this study case, the workers in this company who choose the system of telework, particularly those whose project is suitable, sign a Commitment with the company so that their work can be done in the distance. In this document, there are six clauses which define the terms of this relationship. At the very beginning, the main purpose is indicated: the conciliation between a greater productivity for the company and better qualifyof life for the "collaborator", while the goal is the increase in the competitiveness of the company. The document makes it very clear that the bond is not broken between the company and the "collaborator", saying that it is only a substitution for the route to and from the work place by telecommunications and computing, in such a way that, even in the distance, the worker and the company can keep in touch. The Commitment still says that work in the distance does not imply any kind of additional remuneration nor any kind of differentiated status in comparison to other work mates, thus reaffirming that this type of activity does not substitute the contractual commitments formerly made by the company.

With respect to the organization of the place of work, the document indicates that it is the "collaborator's" exclusive responsibility, while the company should inform about the necessary rules of protection to health, and the company still keeps the right to make previous and periodical inspections of the place of work in order to assure matters of occupational health.

About the equipment to be used, the company takes on the responsibility to provide them, including mobile phones. Benefits such as health plan, life insurance, transportation and meal or food tickets are provided by the company. About work accidents or the occurrence of failure in the equipment, the worker should advise the company immediately. This Commitment has the length of twelve months, and can be renewed as long as it keeps the Collective agreement made in agreement with the unions.

Through the initiative of the company itself, a collective agreement was signed by the two unions mentioned above. The terms of the collective agreement were the same used in the company's Commitment, except for a few changes. The collective agreement also had the validity of twelve months, while it could be renewed in case the company was interested in doing so.

Some countries have specific legislation regarding telework. The case of Portugal is interesting, since in the Portuguese Labor Code, telework is presented in details since 2003. In 2009, with the issue of the new Portu-

\footnotetext{
${ }^{10} 6$ th article of Project of law 4.505.

${ }^{11}$ See: www.camara.gov.br, access on: Oct-18-2011.
} 
guese Labor Code, telework was introduced from articles $165^{\text {th }}$ to $171^{\text {st }}$, dealing with topics that go from conceptualization to the work regime and the utilization of adequate instruments. Telework is classified in this code through the aspect of subordination. Article $165^{\text {th }}$ defines the following: "We consider telework to be work performed with legal subordination, routinely out of the company, and by means of the use of computing and communication technologies." 12

This new Portuguese Code also sets the directions for:

- the contract regime for the subordinate work;

- the regime for the case of a teleworker who had been previously hired by the employer;

- the work instruments in subordinate telework;

- about equal treatment to the worker in a regime of telework;

- about the privacy of the worker in a regime of telework;

- and about the collective representation in a regime of telework ${ }^{13}$.

We do not intend to deepen the issue of international legislation regarding telework. However, we chose to point the existence of important legislation initiatives. Besides the case of Portugal, we can also mention the case of the United States, since, not long ago, in 2010, a law was sanctioned by President Obama, which consisted of a specific legislation on telework, providing legal guidelines for its practice. According to the Social Security Legislative Bulletin, on December $9^{\text {th }}$, 2010, President Obama signed law HR 1722, the "Telework Enhancement Act of 2010", which became public right ${ }^{14}$.

Within the context of the International Labor Organization (ILO), there is no specific regulation on telework. However, when we consider telework performed at home as a modality of home based work, it leads us to ILO's Convention number 177, issued in 1996. This convention intends to establish rules of general application in relation to the work conditions that can be applied to workers at home. One aspect we could consider very important refers to the issue of equal rights of treatment for home based workers and other wage earning workers. In the $4^{\text {th }}$ article, item $2^{15}$, we can find the aspects to be considered in this equivalence:

1) The rights of home based workers to establish or participate in organizations of their choice and participate in their activities;

2) The protection against discrimination in the job and in the occupation;

3) Protection for safety and health;

4) The remuneration;

5) The general protection of social security;

6) Access to training;

7) Minimum age required for admission to the job;

8) Protection to maternity.

We therefore see that this document of ILO is concerned with the issues related to the ways of equivalency of home based work, with other workers. In particular, that the same social guarantees are given in order not to worsen legal conditions for the activities performed at home.

\section{Final Considerations}

Considering the great transformations, the so-called world of labor has been facing a major challenge that happens in what refers to the legal protection to workers. The Labor Law itself has been questioned and new forms of contracts have demanded changes in regulation. As we have seen, with Alain Supiot, there is a "grey zone" between dependent and independent work and he suggests that Labor Law remodels itself in order to include workers who are situated beyond the legal subordination. His perspective is a defense of the permanence of social protection, through the work legislation.

Through subordination, where we define it as symbolic subordination, the employer, in the case of paid telework, uses the mechanisms that are beyond the contractual work relationships that were established. Work in the distance, far from representing work free from coercion mechanisms, in fact, is submitted to these mechanisms in symbolic ways. This control, although not very explicit, is present through symbolic systems of power. The

\footnotetext{
${ }^{12}$ Available in: www.sabiasque.pt/files/0092601029.pdf access on: 03-04-2012.

${ }^{13}$ Idem.

${ }^{14}$ See: http://www.ssa.gov/legislation/legis bulletin 120910.html access on October 18, 2011.

${ }^{15}$ See: http://www.ilo.org/dyn/normlex/fr/f?p=NORMLEXPUB:12100:882674191755941::NO:12100:P12100_ILO_CODE:C177:NO access on March 14, 2012.
} 
worker is led to a set of expectations, such as the possibility of organizing both his schedule and the place of work, where it is argued, he will have more advantages such as the possibility of having more free time etc. Actually, what we could observe through our research is that freedom and autonomy, as announced, do not actually express the real situation. The teleworker, mainly through a system of trust, ends up feeling very obliged to "keep in line", since the feeling of debt is constant. These aspects could be evidenced in the interviews. Much advertisement around telework refers to the possibility of flexibility of schedules of work. Conciliating the professional activities with small every-day spoils, such as having lunch at home, taking children to school and making appointments with doctors etc., can represent a dream work for many people. However, although we do not dismiss the real possibility of some benefit for the workers, what is advertised to them has much more advantages than what really happens. What ends up happening is impossibility to separate private and professional lives, and consequently loss of quality of life by these workers.

\section{References}

[1] Supiot, A. (1999) Au-Delà de L’Emploi. Flammarion, Paris.

[2] Supiot, A. (2007) Homo Juridicus. Ensaios sobre a função antropológica do Direito. WMF Martins Fontes, São Paulo.

[3] Delgado, M.G. (2008) Curso de Labor Law. LTr, São Paulo.

[4] Alemão, I. (2004) Curso de Labor Law. LTr, São Paulo.

[5] de Evaristo, M.F. (1994) Trabalho a domicílio e contrato de trabalho. LTr, São Paulo.

[6] Romita, A.S. (1979) A subordinação no contrato de trabalho. Forense, Rio de Janeiro.

[7] Silva, O.P. (2004) Subordinação, Autonomia e Parassubordinação nas Relações de Trabalho. LTr, São Paulo.

[8] Bourdieu, P. (2001) Meditações Pascalianas. Bertrand Brasil, Rio de Janeiro.

[9] Simbólico, O.P. (2009) CLT-Consolidação das Leis do Trabalho. LTr, São Paulo.

[10] Durkheim, E. and Mauss, M. (1981) Algumas formas primitivas de classificação. Ensaios de Sociologia. Perspectiva, São Paulo.

[11] Sennett, R. (2007) A corrosão do caráter-Consequências pessoais do trabalho no novo capitalismo. Record, Rio de Janeiro. 
Scientific Research Publishing (SCIRP) is one of the largest Open Access journal publishers. It is currently publishing more than 200 open access, online, peer-reviewed journals covering a wide range of academic disciplines. SCIRP serves the worldwide academic communities and contributes to the progress and application of science with its publication.

Other selected journals from SCIRP are listed as below. Submit your manuscript to us via either submit@scirp.org or Online Submission Portal.
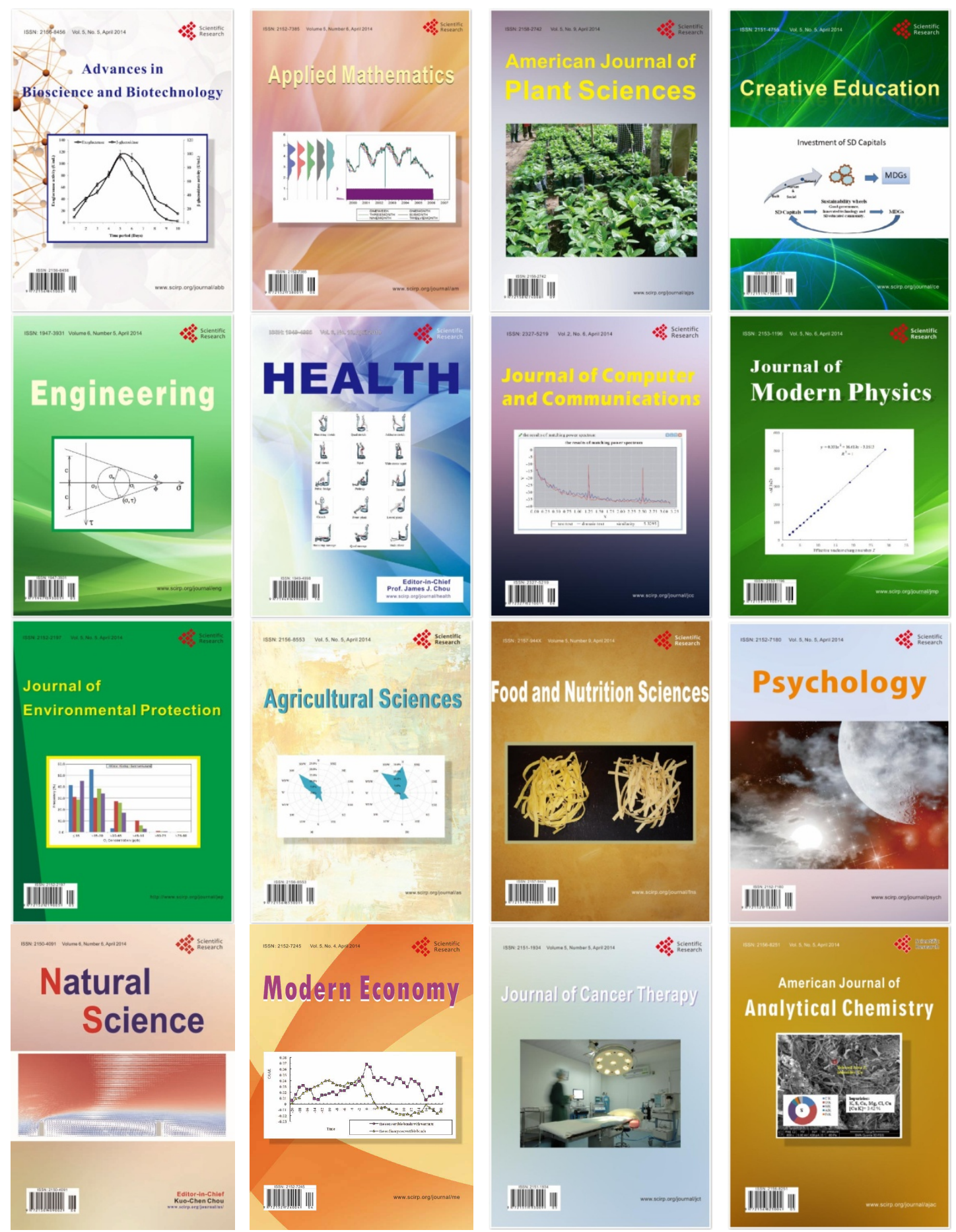